\title{
Hepatic Ultrastructure and Histochemistry in Mucolipidosis II (I-Cell Disease)
}

\author{
Kenneth R. Kenyon ${ }^{[39]}$, Judith A. Sensenbrenner, and Robert G. Wyllie \\ Eye Pathology Laboratory (Wilmer Ophthalmological Institute), Moore Clinic and Department of Pathology \\ of the Johns Hopkins Hospital, Baltimore, and the Laboratory of Vision Research, National Eye Institute \\ and National Institute of Child Health and Human Development, National Institutes of Health, \\ Bethesda, Maryland, USA
}

\begin{abstract}
Extract
In the liver of a 25-month-old patient with mucolipidosis II (I-cell disease), intracellular vacuoles caused marked distension of portal mononuclear cells, sinusoidal Kupffer cells, and granulomatous epithelioid cells. It was determined by electronmicroscopy that these vacuoles were limited by single membranes and contained either fine fibrillogranular material, membranous lamellae, or lipoid globules. Hepatic parenchymal cells were only slightly affected by the storage process, and abnormal extracellular material was not evident. Histochemical staining revealed sudanophilic inclusions within Kupffer cells and demonstrated increased acid phosphatase activity within Kupffer cells and epithelioid cells.
\end{abstract}

\section{Speculation}

The observed intracellular storage vacuoles are possibly derived from altered lysosomes which have accumulated excesses of both acid mucopolysaccharides and glycolipids. The unusual occurrence of epithelioid cell granulomas in this case may reflect the impaired immunologic function of macrophages laden with storage substances.

\section{Introduction}

The mucolipidoses (MLSs) are a recently recognized group of inherited metabolic storage disorders which exhibit features of both the mucopolysaccharidoses and the sphingolipidoses [27]. Mucolipidosis II (MLS II) or I-cell disease was first described in 1967 by Leroy and DeMars [15], who noted coarse cytoplasmic inclusions in cultured fibroblasts (designated "I-cells" or inclusion cells) from two children. Clinically, MLS II is an autosomal recessive trait which becomes evident during the 1st year of life as the affected infant manifests severe psychomotor retardation, early cessation of growth, and facial dysmorphism with characteristic gingival hyperplasia, skeletal dysplasia, thickened skin, and mild hepatomegaly [18]. In contrast to the muco- polysaccharidoses, urinary excretion of acid mucopolysaccharide (AMP) is not increased [27]. Histochemical and biochemical studies of liver and cultured fibroblasts have disclosed increased amounts of total AMP and various lipids $[2,9,12,24]$. The pathogenesis of MLS II is uncertain, but deficiencies of $\beta$-galactosidase and other lysosomal acid hydrolases in liver, brain, and cultured fibroblasts [15-19, 23, 27, 31, 37] favor the possibility of an inborn lysosomal disorder [11].

Histopathologic reports of MLS II are limited. The histochemistry and ultrastructure of cultured I-cells have been investigated by DeMars and Leroy [5] and by Hanai et al. [9]. Blumcke and associates [2] have reported hepatic ultrastructure briefly in one case of MLS II. Tondeur and coworkers [31] studied extensively a 3.5 -year-old I-cell patient with respect to histo- 
chemistry and electronmicroscopy of liver, kidney, skin, brain, bone, and cultured fibroblasts. We have also reported the ultrastructure of conjunctiva and skin from a 25-month-old patient with MLS II [14]. The present report describes the hepatic histochemistry and ultrastructure of the I-cell patient we had studied previously.

\section{Materials and Methods}

The clinical history of the patient has been reported previously [14]. Of particular relevance to the present study is the physical finding of hepatic enlargement to $8 \mathrm{~cm}$ below the right costal margin. Liver function studies included cholesterol 231, total bilirubin 0.3 , thymol turbidity 0.2 (normal: $<0.5$ ), prothrombin time $\sim 80 \%$ normal, lactic dehydrogenase (LDH) 338 (normal: $<300$ ), serum glutamic oxaloacetic transaminase (SGOT) 33 (normal: <19), and serum glutamic pyruvic transaminase (SGPT) 22 (normal: $<17$ ).

Liver tissue was obtained by open biopsy under general anesthesia and was immediately processed for histochemistry and electronmicroscopy.

For histochemical study, unfixed frozen sections $(\sim 6$ $\mu$ thick) were stained with hematoxylin-eosin, toluidine blue $(0.5 \%$ aqueous, with and without chloroform-methanol pretreatment [24]), Alcian blue $(0.5 \%$ in $0.1 \mathrm{~N} \mathrm{HCl}, \mathrm{pH} 2.5)$, periodic acid-Schiff, aldehyde fuchsin, oil red $\mathrm{O}$, and Sudan black $0.7 \%$ in $5 \%$ aqueous Tween-80, with and without chloroformmethanol pretreatment [24]). The activities of the lysosomal enzymes, acetyl esterase, ribonuclease, acid phosphatase, and $\beta$-glucuronidase were also demonstrated by standard histochemical techniques $[1,4,10]$ on fresh unfixed frozen sections.

For electronmicroscopy, tissue was fixed in $2 \%$ osmium tetroxide buffered to $\mathrm{pH} 7.3$ with veronal acetate $(0.14 \mathrm{M}, 280 \mathrm{mosmol})$ for $20 \mathrm{~min}$ at $0^{\circ}$, followed by $1 \mathrm{hr}$ at room temperature. The tissue was then dehydrated in graded alcohols, embedded in Araldite epoxy resin, and sectioned on a Porter-Blum MT-2 ultramicrotome. For orientation and photomicrography, thick sections $(\sim 1 \mu)$ were stained with paraphenylene diamine. Thin sections were stained with uranyl acetate and lead citrate, and were examined with a JEM 100-B electron microscope.

\section{Results}

\section{Light Microscopy}

The lobular architecture of the liver was well preserved. The hepatocytes, bile duct epithelium, and vas- cular endothelium appeared entirely normal, and in particular, no vacuolation could be detected. The portal areas contained numerous mononuclear cells with foamy cytoplasm (Fig. 1, inset). In the intralobular areas, Kupffer cells were enlarged, and their cytoplasm showed the same foamy appearance. Granulomas composed of large epithelioid cells with finely vacuolated cytoplasm occurred near some of the portal triads (Figs. 6 and 7). Special stains for fungi and acid-fast bacilli were negative, and neither necrosis nor inflammation was evident.

\section{Histochemistry}

Excesses of AMP were not evident in any of the vacuolated cells by either toluidine blue, Alcian blue, periodic acid-Schiff, or aldehyde fuchsin techniques. Accumulations of Sudan black-positive material appeared only within Kupffer cells (Fig. 3). This material was removed by chloroform-methanol extraction and did not stain with oil red $O$. In comparison to normal liver tissue, staining for acid phosphatase activity was enhanced within Kupffer cells and especially within epithelioid cell granulomas. Stains for other lysosomal enzymes (glucuronidase, ribonuclease, and acetyl esterase) did not show increased activity in any cell type.

\section{Electron Microscopy}

Hepatic parenchymal cells did not show significant ultrastructural alterations. Neither large storage vacuoles nor other abnormal cytoplasmic inclusions were seen. A few small peribiliary lysosomes, containing fine granular material in addition to their usual electrondense substances, appeared to be minimally involved in the storage process (Fig. 9). Nuclei, endoplasmic reticulum, and mitochondria also appeared unremarkable. The amount and distribution of glycogen were normal.

The foamy mononuclear cells in the portal areas were markedly enlarged, often measuring $\sim 15 \mu$ or more in diameter (Fig. 1). In these cells, extreme accumulation of fine granular or globular material interspersed with membranous lamellar inclusions had produced an alveolar reticulum of membranous septae and caused displacement of the normal cytoplasmic organelles (Fig. 2).

Most of the Kupffer cells were distended by numerous cytoplasmic vacuoles which measured $\sim 0.5-2.0 \mu$ in diameter (Fig. 4). These vacuolar inclusions were bounded by single membranes and contained pleomorphic material in the form of sparse fibrillogranular substance, membranous lamellae (Fig. 5), and lipoid 


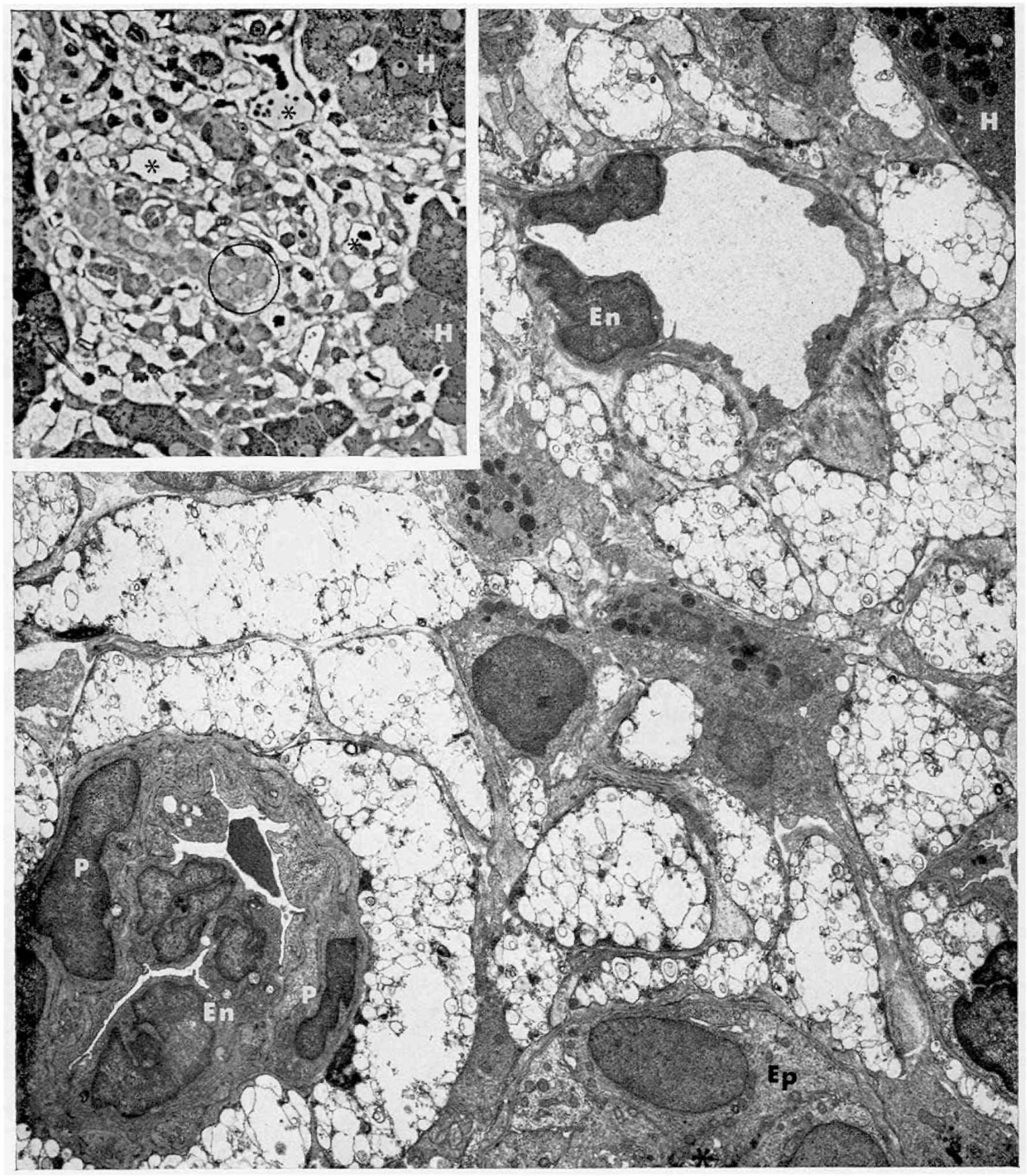

Fig. 1. Inset: Light photomicrograph of hepatic portal area reveals extensive infiltration by large mononuclear cells with foamy cytoplasm. Hepatocytes $(H)$, bile duct (circled), and portal vessels $\left(^{*}\right)$ appear unaffected. (Paraphenylenediamine, phase contrast, $\times 600$.) Survey electronmicrograph of portal area shows numerous monuclear cells which are markedly distended by storage material. As in inset, hepatocytes $(H)$ and biliary epithelial cells $(E p)$ are not vacuolated. Vascular endothelial cells $(E n)$ and perithelial cells $(P)$, containing few small vacuoles, are within normal limits. (*: bile duct lumen, $\times 5,300$.) 


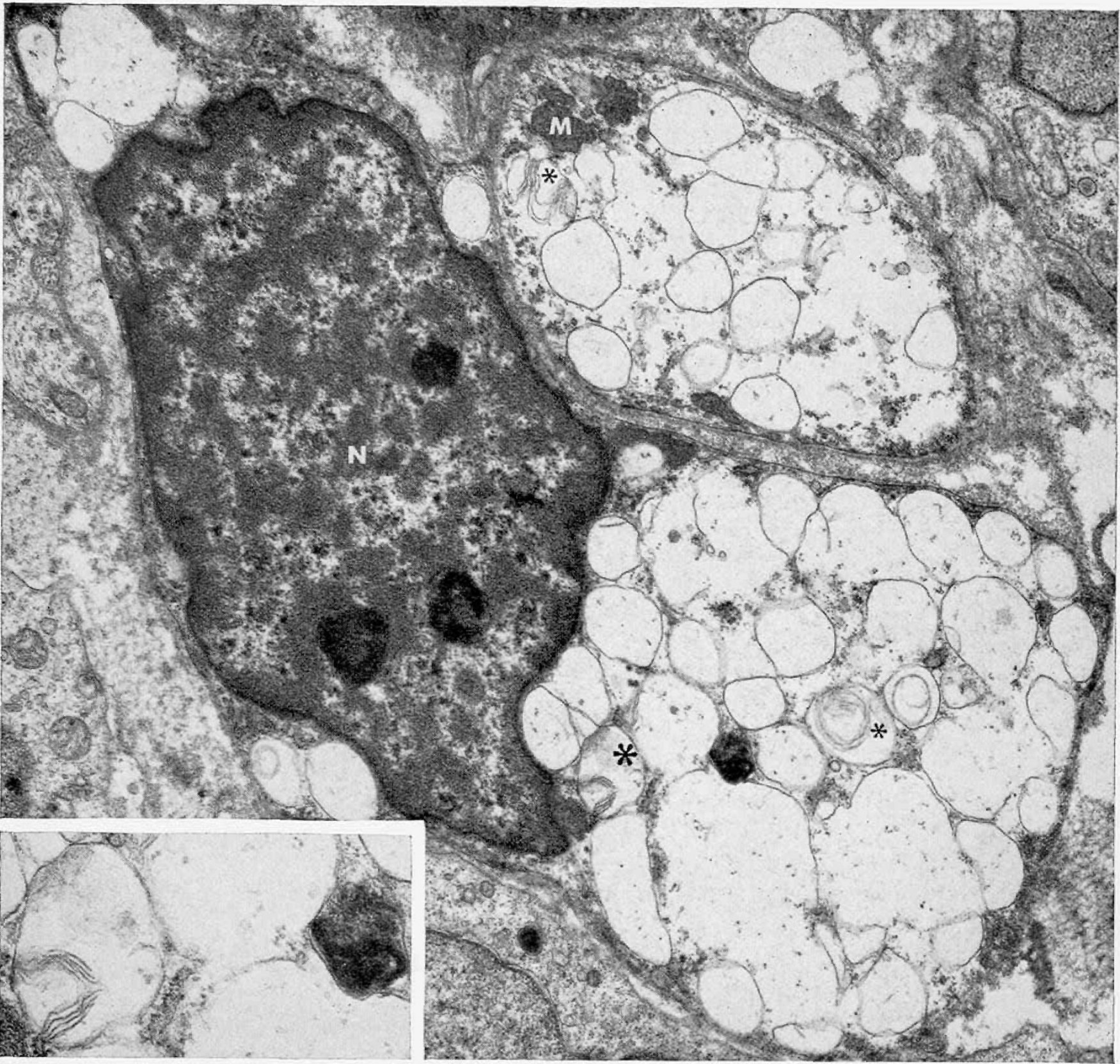

Fig. 2. Electronmicrograph of portal monuclear cell demonstrates reticulated cytoplasm dominated by storage vacuoles with either fine granular or membranous lamellar $\left({ }^{*}\right)$ contents. Unmyelinated nerve fibers (upper left) do not display storage vacuoles. Inset: Higher magnification of area indicated by large asterisk reveals single limiting membrane of the storage vacuole and parallel array of lamellar membranes. Electron-dense inclusion also contains membranous material. ( $N$ : nucleus; $M$ : mitochondrion; $\times 18,400 ;$ inset, $\times 40,000$.)

globules. All three inclusion types could often be found within a single cell.

In the granulomatous areas, epithelioid cells were extensively vacuolated by small $(<1.0 \mu$ diameter $)$, discrete, single membrane-limited inclusions with sparse granular or membranous lamellar contents (Fig. 8).
Nuclei and other cytoplasmic organelles were always visible within these cells.

Abnormal intracellular inclusions could not be identified within the bile duct epithelial cells. Vascular and lymphatic endothelial and perithelial cells did not contain vacuoles in excess of those which are normally 

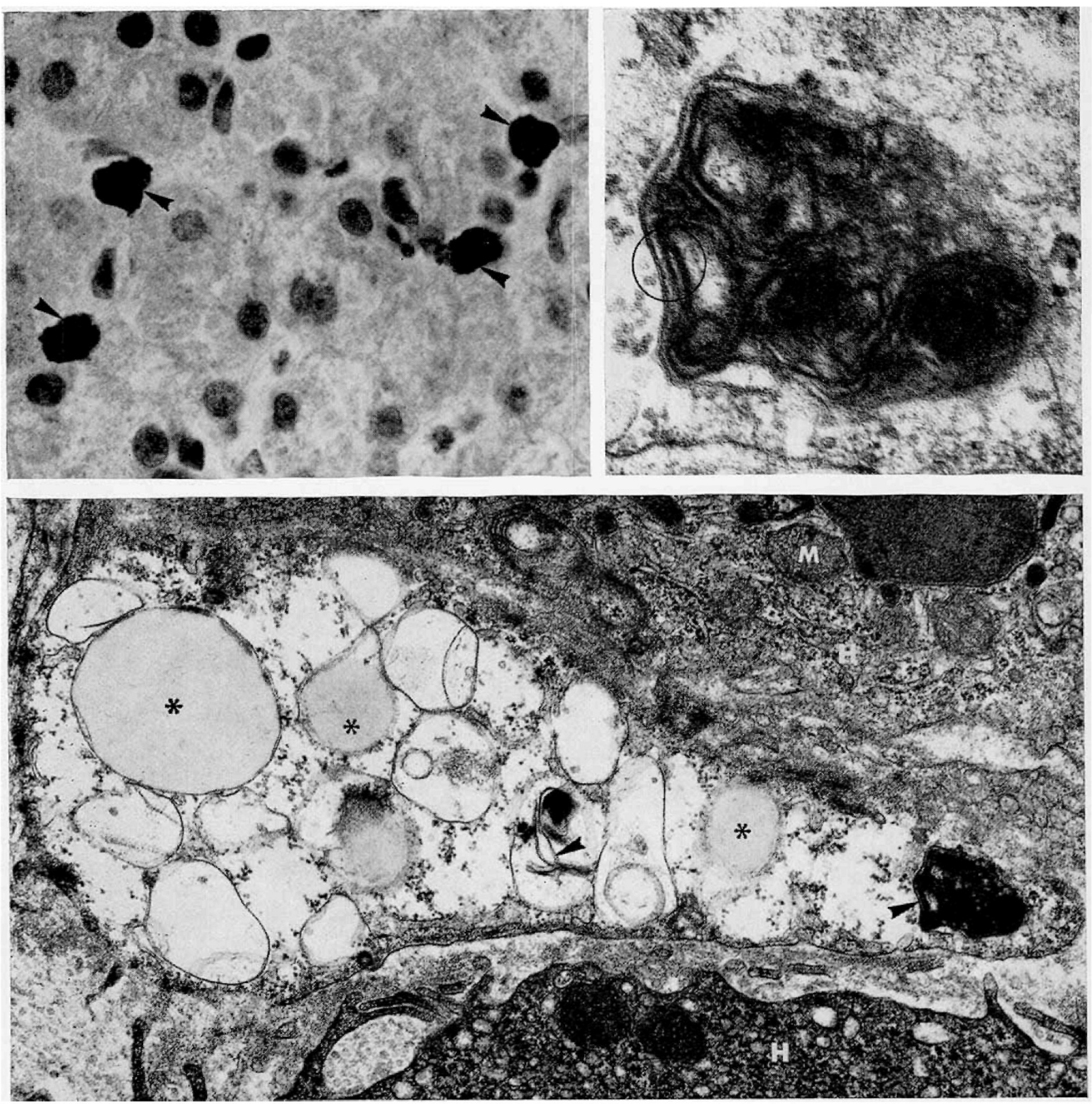

Fig. 3 (top left). Light micrograph of frozen histologic section shows sudanophilic material (arrows) within Kupffer cells. (Sudan black $\times$ 800.)

Fig. 4 (bottom). Electron micrograph of Kupffer cell discloses membrane-limited vacuolar inclusions, containing either sparse fibrillogranular material, membranous lamellae (arrows), or large lipoid globules $\left({ }^{*}\right)$. ( $H$ : hepatocyte; $M$ : mitochondrion, $\times 28,000$.)

Fig. 5 (top right). At higher magnification (cf. Fig. 4), the $\sim 60-\AA$ thickness of the membranous lamellae (circled) within a Kupffer cell can be resolved. $(\times 100,000$. $)$ 

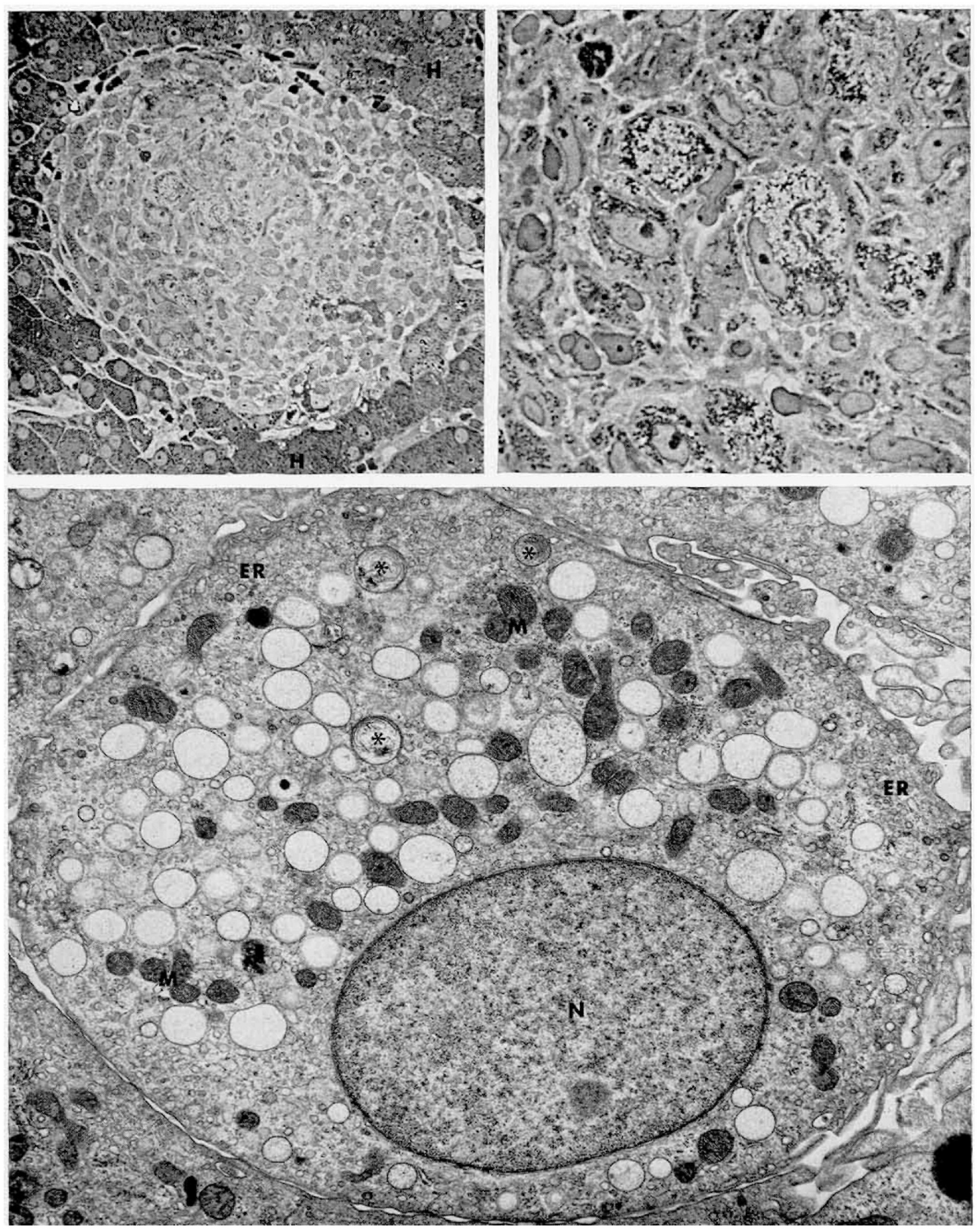

Fig. 6 (top left). Low magnification light photomicrograph illustrates a granuloma composed of large monuclear epithelioid cells. ( $H$ : hepatocytes, paraphenylenediamine, phase contrast, $\times 400$.)

Fig. 7 (top right). At higher magnification of granulomatous area shown in Fig. 6, the fine cytoplasmic vacuolation of the epithelioid cells is evident. (Paraphenylenediamine, phase contrast, $\times 1,200$.)

Fig. 8 (bottom). Electronmicrograph of a granulomatous epithelioid cell demonstrates numerous discrete, membrane-limited vacuoles with sparse granular or membranous lamellar $\left(^{*}\right)$ content. Mitochondria $(M)$ and cisternae of smooth endoplasmic reticulum $(E R)$ are frequent. $(N$ : nucleus, $\times 14,000$.) 


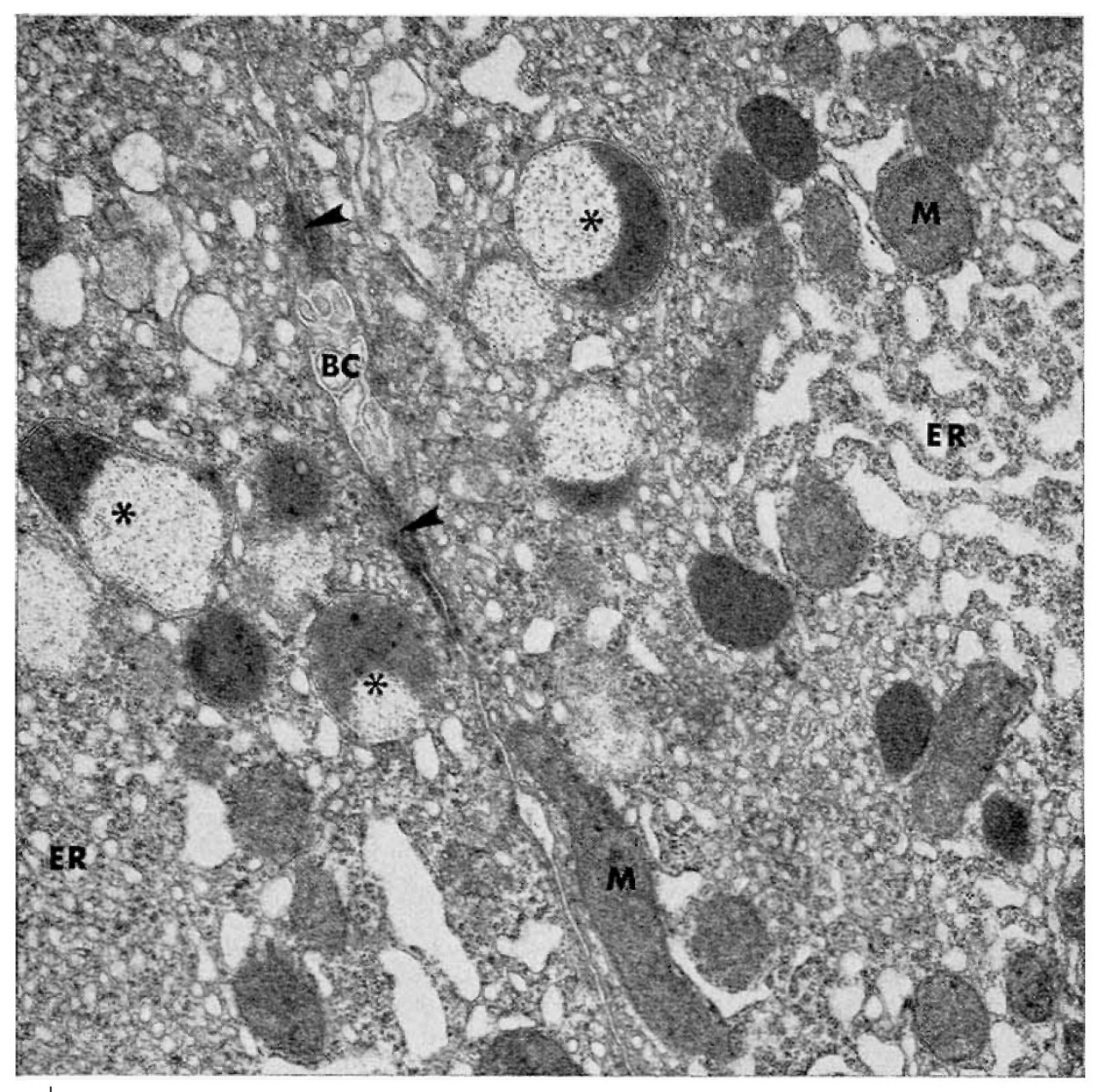

Fig. 9. Electronmicrograph of adjacent hepatocytes and bile canaliculus $(B C)$ shows few lysosomes $\left({ }^{*}\right)$ of normal size with single limiting membranes and both granular and electron-dense contents. ( $M$ : mitochondrion; $E R$ : endoplasmic reticulum; arrows, junctional complexes, $\times 20,000$.)

present. No unusual extracellular or intravascular material was evident.

\section{Discussion}

In the liver of this 25-month-old child with MLS II, the most distinctive pathologic alteration was the presence of intracellular vacuoles limited by single membranes and containing either fine fibrillogranular material, membranous lamellae, or lipoid globules. Such vacuolar storage inclusions distended portal mononuclear cells, sinusoidal Kupffer cells, and granulomatous epithelioid cells. Hepatocytes showed only slight evidence of intralysosomal storage. Vascular endothelium and biliary epithelium were not visably affected, and abnormal extracellular material was nowhere evident. Morphologically identical material has previously been identified in hepatic tissues of MLS II patients $[2,31]$, as well as in other mucolipidoses, including fucosidosis [2, 7, 21], $\mathrm{G}_{\mathrm{M}_{1}}$-gangliosidosis [28, 29], and MLS I [6, 22]. Moreover, in cultured fibroblasts and in various other tissues affected by MLS II, similar storage inclusions have been observed consistently by electronmicroscopy $[5,9,14,31]$.

An unusual feature of the present case is the prominent involvement of mesenchymally derived cells (Kupffer cells and other macrophages) with relative sparing of epithelially derived hepatocytes. Among the MLS's, Blumcke et al. [2] have similarly noted a general tendency toward more severe involvement of the mesenchymal system. In both previous reports of hepatic ultrastructure in MLS II, however, significant hepatocellular vacuolation was evident even though involvement of portal mononuclear cells and Kupffer 
cells appeared much less severe than in the present case $[2,31]$. Extensive vacuolation of hepatocytes has also been noted consistently in many other AMP and glycolipid disorders, including mucopolysaccharidosis types $I-I I I[3,20,33,34]$, fucosidosis $[7,21], \mathrm{G}_{\mathrm{M}_{1}-}$ gangliosidosis [28, 29], and MLS I [6, 22]. Only in mucopolysaccharidosis type IV [30] and in Goldberg's MLS I variant [8] is vacuolation confined to Kupffer cells without hepatocellular alteration.

Another unusual aspect of this case is the epithelioid cell granulomas which have not, to our knowledge, been described in connection with other storage disorders. The extensive vacuolar inclusions of the epithelioid cells and their enhanced acid phosphatase activity indicate that these cells are reactive macrophages involved primarily in the storage process. Increasing evidence also indicates that antigen processing and other activities of macrophages are essential components of the normal immune response [36]. In the present case, therefore, macrophages overloaded with indigestible storage substances might be functionally impaired to the extent that the affected individual would be susceptible to low grade pathogens. The observed hepatic granulomas possibly betray the presence of subclinical infection in our I-cell patient.

Histochemical staining has repeatedly revealed intracellular AMP accumulations in cultured fibroblasts of MLS II patients [9, 15, 24, 31], but not in their liver, kidney, brain, and conjunctiva [14, 31]. Indications for storage of complex lipids are afforded by the sudanophilic inclusions in cultured I-cells [9, 15, 24] and in hepatic Kupffer cells of this patient, as well as by ultrastructural observations of membranous lamellae or myelin-like inclusions $[13,14,26,32]$. Furthermore, since AMP and complex lipid have been isolated from hepatic tissue and cultured fibroblasts of MLS II patients, it is reasonable to suppose that these substances are present in affected cells in vivo. These approaches, however, give no in vivo information about whether the AMP and complex lipid are separate or are in some way bound to each other. If, for example, and AMP-lipid complex were to exist in a configuration that would mask their specific stainbinding sites, then the observed lack of histochemical staining of various MLS II tissues could be explained.

The concept of inborn lysosomal diseases has been postulated for several classes of storage disorders in which a deficiency of lysosomal hydrolytic enzymes may result in inadequate degradation of substances which then progressively accumulate within lysosomal storage vacuoles [11]. Although the origin of the stor- age vacuoles in MLS II has not been firmly established, their derivation from lysosomes seems likely. Certainly the enhanced acid phosphatase activity of the vacuolated cells, the single limiting membrane of the storage vacuoles, and the dearth of typical lysosomes satisfy the criteria for lysosomes. No specific enzyme defect has yet been characterized for MLS II. In cultured I-cells, the activities of multiple acid hydrolases are markedly depressed, whereas others, including acid phosphatase, are elevated [15, 17, 19, 31]. In brain and liver tissues of I-cell patients, reduced $\beta$-galactosidase activity has been found with some consistency, although activities of other acid hydrolases are variably altered $[17,23,27,31]$. The liver tissue of our patient similarly demonstrates this pattern in its markedly reduced $\beta$-galactosidase activity but somewhat increased activities of $\beta$ - $N$-acetyl glucosaminidase and $\beta$-glucuronidase [25]. Recently, Wiesmann and coworkers [37] have found that cultured I-cells release lysosomal hydrolases into their culture medium and have postulated that the multiple enzyme deficiencies of I-cell tissues are the consequence of a diffuse leakage of hydrolytic enzymes.

\section{References and Notes}

1. BARKa, T.: A simple 420 dye method for histochemical demonstration of acid phosphatase. Nature, 187: 248 (1960).

2. Blumcke, S., Freitac, F., and Spranger, J.: Comparative ultrastructural investigations of livers in mucopolysaccharidoses and mucolipidoses. Verh. Deut. Ges. Pathol. 55: 394 (1971).

3. Callahan, W. P., and Lorincz, A. E.: Hepatic ultrastructure in the Hurler syndrome. Amer. J. Pathol. 48: 277 (1966).

4. Davis, B. J., AND Ornstein, L.: High resolution enzyme localization with a new diazo reagent, "hexazonium pararosanilin." J. Histochem. Cytochem., 7: 291 (1959).

5. DeMars, R. I., and Leroy, J. G.: The remarkable cells cultured from a human with Hurler's syndrome. In Vitro, 2: 107 (1967).

6. Freitag, F., Blumcke, S., and Spranger, J.: Hepatic ultrastructure in mucolipidosis I (lipomucopolysaccharidosis). Virchows Arch. Abt. B Zellpathol., 7: 189 (1971).

7. Freitag, F., Kuchemann, K., Blumcke, S., and Spranger, J.: Hepatic ultrastructure in fucosidosis. Virchows Arch. Abt. B Zellpathol., 7: 99 (1971).

8. Goldberc, M. F., Cotlier, E., Fichenscher, L. G., Kenyon, K. R., Enat, R., ANd Borowsky, S. A.: A new storage disease characterized by beta-galactosidase deficiency, macular cherry red spot and corneal clouding. Arch. Intern. Med., 128: 387 (1971).

9. HaNAI, J., Leroy, J., AND O'Brien, J. S.: Ultrastructure of cultured fibroblasts in I-cell disease. Amer. J. Dis. Child., 122: 34 (1971).

10. Hayashi, M., Nakajima, Y., and Fishman, W. H.: The cytologic demonstration of beta-glucuronidase employing naphthol AS-BI glucuronide and hexazonium pararosanilin. J. Histochem. Cytochem., 12: 293 (1964). 
11. Hers, H. G.: Inborn lysosomal diseases. Gastroenterology, 48: $625(1965)$.

12. Hof, L., Matalon, R., and Dorfman, A.: Gangliosides in human skin fibroblasts and their enrichment in the "Hurler variant" and Krabbe's disease. Hoppe-Seyler's Z. Physiol. Chem., 352: 1329 (1971).

13. Kenyon, K. R., Quigley, H. A., Hussels, Y. E., Wyllie, R. G., AND GOLDBERG, M. F.: The systemic mucopolysaccharidoses: Ultrastructural and histochemical studies of conjunctiva and skin. Amer. J. Ophthalmol., 73: 811 (1972).

14. KenYon, K. R., and SENSENBRENNER, J. A.: Mucolipidosis II (I-cell disease): Ultrastructural observations of conjunctiva and skin. Invest. Ophthalmol., 10: 555 (1971).

15. Lerox, J. G., and DeMars, R. I.: Mutant enzymatic and cytological phenotypes in cultured human fibroblasts. Science, 157: 804 (1967).

16. Leroy, J. G., DeMars, R. I., and OpItz, J. M.: I-cell disease. In: Clinical Delineation of Birth Defects, Vol. 6, Sect. IV. p. 174. (Original Article Series, National Foundation, March of Dimes, 1969).

17. Leroy, J. G., and Spranger, J. W.: I-cell disease (cont.). New Engl. J. Med., 283: 598 (1970).

18. Leroy, J. G., Spranger, J. W., Feingold, M., OptTz, J. M., and Crocker, A. C.: I-cell disease: A clinical picture. J. Pediat., 79: 360 (1971).

19. Lightbody, J., Wiesmann, U., Hadorn, B., and HerschkowrTz, N.: I-cell disease: Multiple lysosomal enzyme defect. Lancet, I 83: 451 (1971).

20. Loeb, H., Jonniaux, G., Resibots, A., Cremer, N., Dodion, J., Tondeur, M., Gregoire, P., Richard, J., and Cieters, P.: Biochemical and ultrastructural studies in Hurler's syndrome. $\mathrm{J}$. Pediat., 73: 860 (1968).

21. Loeb, H., Tondeur, M., Jonniaux, G., Mockelpohl, S., and VAMOs-HURwitz, E.: Biochemical and ultrastructural studies in a case of mucopolysaccharidosis " $F$ " (fucosidosis). Helv. Paediat. Scand., 58: 519 (1969).

22. Loeb, H., Tondeur, M., Topper, M., and Cremer, N.: Clinical, biochemical and ultrastructural studies of an atypical form of mucopolysaccharidosis. Acta Paediat. Scand., 58: 220 (1969).

23. Luchsinger, U., Buhler, E. M., Menes, K., and Hirt, H. R.: I-cell disease. New Engl. J. Med., 282: 1374 (1970).

24. Matalon, R., Cifonelli, J. A., Zellweger, H., and Dorfman, A.: Lipid abnormalities in a variant of the Hurler syndrome. Proc. Nat. Acad. Sci. U.S.A., 59: 1097 (1968).

25. O’Brien, J. S.: Personal communication.

26. QUigley, H. A., AND GoldBeRg, M. F.: Conjunctival ultrastruc- ture in mucolipidosis III (pseudo-Hurler polydystrophy). Invest. Ophthalmol. 10:568 (1971).

27. Spranger, J. W., and Wiedemann, H. R.: The genetic mucolipidoses: Diagnosis and differential diagnosis. Humangenetik, 9: 113 (1970).

28. SuzukI, K., SuzukI, K., AND CheN, G.: Morphological, histochemical and biochemical studies on a case of systemic late infantile lipidosis (generalized gangliosidosis). J. Neuropath. Exp. Neurol., 27: 15 (1968).

29. Themann, H., Diekmann, L., and Bassewrtz, D. B.: Die Feinstruktur der menschlicken Leber bei Generalisierter Gangliosidose $G_{M 1}$. Beitr. Pathol. Anat. Allg. Pathol, 140: 194 (1970).

30. Tondeur, M., And Lorb, H.: Etude ultrastructurelle du faie dans la maladie de Morquio. Pediat. Res., 3: 19 (1969).

31. Tondeur, M., Vamos-Hurwitz, E., Mockélpohl, S., Dereume, J. P., Cremer, N., ANd Loeb, H.: Clinical, biochemical and ultrastructural studies in a case of chondrodystrophy presenting the I-cell phenotype in tissue culture. J. Pediat., 79: 366 (1971).

32. Topping, T. M., Kenyon, K. R., Goldberg, M. F., and MaUMENEE, A. E.: Ultrastructural ocular pathology of Hunter's syndrome (systemic mucopolysaccharidosis type II). Arch. Ophthalmol., 86: 164 (1971).

33. VANHoor, F., AND HERS, H. G.: L'ultrastructure des cellules hepatiques dans la maladie de Hurler. C. R. Acad. Sci. (Paris), 259,1281 (1964).

34. Wallace, B. J., Kaplan, D., Adachi, M., Schneck, L., and VoLK, B.: Mucopolysaccharidosis type III: Morphologic and biochemical studies of two siblings with Sanfilippo syndrome. Arch. Pathol., 82: 462 (1966).

35. Wallace, B. J., Volk, B. W., and Lazarus, S. C.: Fine structural localization of acid phosphatase activity in neurons of Tay-Sachs disease. J. Neuropathol. Exp. Neurol., 23: 676 (1964).

36. Weisman, G., And Dukor, P.: The role of lysosomes in immune responses. Advan. Immunol., 12: 283 (1970).

37. Wiesmann, U. N., Lightbody, J., Vassella, F., and HerschoowrTz, N. N.: Multiple Iysosomal enzyme deficiency due to enzyme leakage? New Engl. J. Med., 284: 109 (1971).

38. This study was supported in part by a grant-in-aid from Fight for Sight, Inc., New York City.

39. Requests for reprints should be addressed to. KENNETH $R$. KenYon, M. D.: Eye Pathology Laboratory, Wilmer Institute, Johns Hopkins Hospital, 601 N. Broadway, Baltimore, Md. 21205 (USA).

40. Accepted for publication January 5, 1973. 